\title{
Chapter 15 \\ Spatially Disaggregated Impact Pathway Analysis of Direct Particulate Matter Emissions
}

\author{
Janusz Zyśk, Artur Wyrwa, and Beata Sliz-Szkliniarz
}

\begin{abstract}
This chapter focuses on the evaluation of air quality and health impacts associated with direct emissions of air pollutants for different REFLEX scenarios based on the Driver-Pressure-State-Impact-Response framework. Ambient concentration of air pollutants is calculated with the use of the Polyphemus Air Quality System. Health impacts are calculated using the concentration-response functions. Results show that particulate matter emissions in Europe will decrease by 10 times till 2050. Also ambient pollutants concentrations decrease in 2050 in all REFLEX scenarios. This leads to the reduction of external costs of almost 20 billion EUR per year.
\end{abstract}

\subsection{Introduction}

This study focuses on the evaluation of air quality and health impacts that are associated with direct emissions of air pollutants in the EU-27, Norway, Switzerland and United Kingdom. Direct emissions result mainly from the combustion of fossil fuels during the operational phase of energy technologies. The subject is of great importance for EU citizens as air pollution leads to significant damage to human health, environment, buildings and other materials. Exposure of humans to elevated concentrations of air pollutants increases morbidity leads to premature mortality and shortening the life expectancy (WHO 2018; EEA 2016). The contribution of different economic sectors to primary emissions depends on the pollutant considered. For instance, the residential sector was the largest contributor to particulate matter emissions in 2018, contributing to $47 \%$ and $61 \%$ of total $\mathrm{PM}_{10}$ and $\mathrm{PM}_{2.5}$ emission in EU-27 Norway, Switzerland and United Kingdom, respectively (EMEP 2018). In the same year, the energy production and distribution sector was the largest

J. Zyśk · A. Wyrwa (凶)

AGH University of Science and Technology, Krakow, Poland

e-mail: awyrwa@agh.edu.pl

B. Sliz-Szkliniarz

European Institute for Energy Research (EIfER), Karlsruhe, Germany 
contributor to total $\mathrm{SO}_{2}$ and road transport to $\mathrm{NO}_{\mathrm{x}}$ emissions. There is no doubt that progress has been made in EU in the last twenty years in reducing emissions of the main air pollutants due to implementation of relevant legislation (e.g. Directive EU 2010). Substantial emission reduction of pollutants such as $\mathrm{PM}_{2.5}, \mathrm{PM}_{10}$, $\mathrm{SO}_{\mathrm{x}}, \mathrm{NO}_{\mathrm{x}}$, NMVOCs (Non-methane volatile organic compounds) has been achieved in particular in the energy production and distribution as well as in road transport sectors. Still, however, in many regions of the European Union, the current limits on ambient pollutant concentrations are often exceeded (EEA 2016). Estimations show that even $24 \%, 30 \%, 19 \%$ of urban population in the EU-27, Norway, Switzerland and United Kingdom is exposed to $\mathrm{B}(\mathrm{a}) \mathrm{P}$ (Benzo(a)pyren), $\mathrm{O}_{3}$ and $\mathrm{PM}_{10}$ concentrations, respectively, that are above the EU reference values (EEA 2016; Directive EU 2008).

This study, following the DPSIR (Driver-Pressure-State-Impact-Response) framework (Guariso and Volta 2017), assesses how the implementation of energy scenarios elaborated within the REFLEX project would impact the future air quality, residents' health and external costs. The air quality modeling system Polyphemus is used to analyze the changes in future ambient pollutants concentration. Then, using the data on population density distribution and results of epidemiological studies the health impacts of air pollution are estimated. Finally, the monetary valuation of health damages is carried out and the values of the so- called external costs associated with different energy scenarios are compared.

\subsection{Description of the Method}

The approach to calculate the external costs of direct pollutant emissions is based on the Driver-Pressure-State-Impact-Response (DPSIR) framework depicted in Fig. 15.1 (Wyrwa 2015). Based on the chain of causality human caused drivers (use of primary energy sources) are linked to pressures on the environment (emissions),

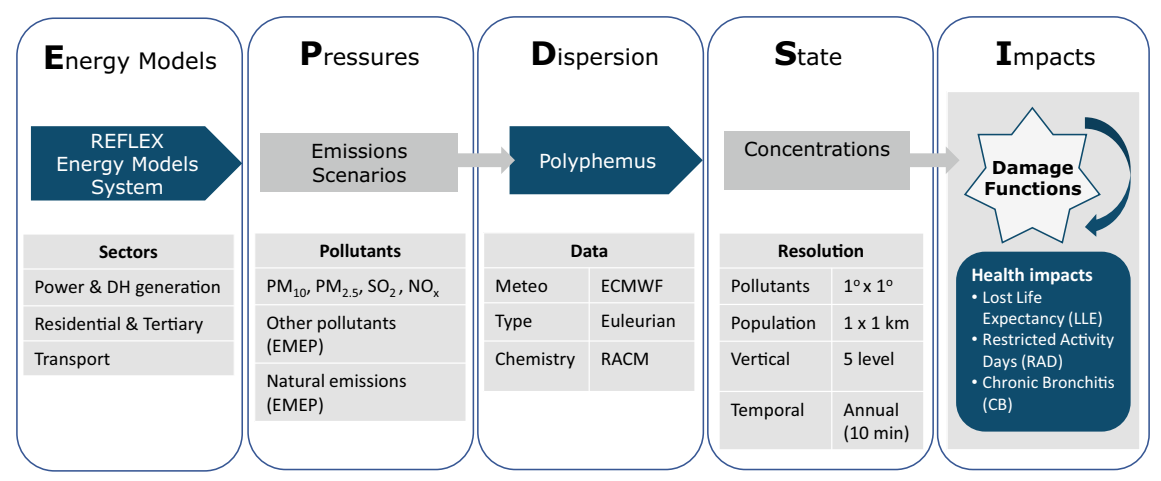

Fig. 15.1 The steps of analysis of external costs of direct emissions. (Source Own illustration) 
changes of environmental states (air quality, human health) and eventually responses to correct the situation (constraints imposed on energy scenarios). "Drivers", "Pressures" and "Responses" are addressed with the "REFLEX energy models system", whereas "States", including the level of ambient air concentration and deposition of pollutants, were covered by Polyphemus - a full system for air quality modeling. Analysis of the health impact is limited to people's long-term exposure to fine particulate air pollution.

\subsubsection{Emission Scenarios}

Emissions scenarios are prepared based on the results of the ELTRAMOD, TIMESHeat-EU, ASTRA and FORECAST models for different REFLEX scenarios. All REFLEX energy models provide results on $\mathrm{CO}_{2}$ emissions. However, they lack information on emissions of air pollutants, such as $\mathrm{SO}_{2}, \mathrm{NO}_{\mathrm{x}}, \mathrm{PM}_{\mathrm{s}}$ which need to be taken into account in air quality modeling. The results of these models as regards to electricity, district heat generation or final fuel consumption (so called activity) are used together with the relevant emission factors for different pollutants to derive the emission scenarios. The emission factors for ELTRAMOD are taken from the ECOINVENT database and modified according to efficiency improvements of power generation technologies assumed in the ELTRAMOD model. The emission factors for TIMES-Heat-EU are extracted from the GAINS model (GAINS 2019). In case of the FORECAST model, the results on final fuel consumption in the residential and tertiary sectors are used together with emission factors for combustion installations meeting the current Ecodesign limits (Commission Regulation [EU] 2015). With reference to the transport sector, the results of the ASTRA model in terms of Tankto-Wheel yearly emissions are provided by TRT ${ }^{1}$. Emissions are related to land modes (road, rail, inland waterways) for both passenger and freight transport demand, as well as air passenger mode and freight maritime ship mode. Emissions from air mode are treated by separating the contribution of the LTO cycle (landing and take-off) and the cruise phase, because the vertical level of these emissions is different (they are released at different heights what influence their atmospheric dispersion).

The air quality model requires information also on natural and anthropogenic emissions. The REFLEX energy system models, however, do not cover all the economic sectors that generate emissions. Therefore, the missing dataset is complemented with emission inventories of the European Monitoring and Evaluation Programme (EMEP 2018). There are two simulation cases considered for anthropogenic emissions: (i) historical emissions reported to EMEP for 2015, and (ii) REFLEX emissions (all scenarios) for 2050 for power and district heat sector, road transport, households and tertiary (remaining emissions were again complemented with the EMEP data). The REFLEX emissions are distributed horizontally based on the EMEP emission data for 2015. Table 15.1 shows the emissions of pollutants in

\footnotetext{
${ }^{1}$ TRT Trasporti e Territorio: responsible project partner for transport modeling.
} 
Table 15.1 Total $\mathrm{PM}_{10}$ emissions in 2015 and in 2050 (Mod-RES) [Mg]

\begin{tabular}{|c|c|c|c|c|c|c|}
\hline \multirow[b]{3}{*}{ Year } & \multicolumn{6}{|l|}{ Sector } \\
\hline & \multicolumn{2}{|c|}{ Residential \& Tertiary } & \multicolumn{2}{|c|}{ Road Transport } & \multicolumn{2}{|c|}{$\begin{array}{l}\text { Power \& District Heat } \\
\text { Generation }\end{array}$} \\
\hline & 2015 & 2050 & 2015 & 2050 & 2015 & 2050 \\
\hline \multicolumn{7}{|c|}{ country } \\
\hline AT & 8,451 & 549 & 3,914 & 1,358 & 1,056 & 353 \\
\hline $\mathrm{BE}$ & 13,281 & 510 & 5,455 & 1,983 & 416 & 239 \\
\hline BG & 25,055 & 137 & 3,383 & 521 & 1,372 & 38 \\
\hline $\mathrm{CH}$ & $2,, 467$ & 707 & 3,304 & 1,015 & 70 & 11 \\
\hline CY & 82 & 29 & 496 & 41 & 323 & 8 \\
\hline $\mathrm{CZ}$ & 30,449 & 664 & 3,902 & 1,200 & 2,297 & 180 \\
\hline $\mathrm{DE}$ & 22,148 & 6,040 & 29,571 & 11,328 & 9,304 & 913 \\
\hline DK & 14,954 & 296 & 2,505 & 618 & 446 & 135 \\
\hline $\mathrm{EE}$ & 2,722 & 79 & 538 & 117 & 4016 & 832 \\
\hline ES & 55,023 & 1,267 & 15,178 & 6,599 & 6,498 & 131 \\
\hline FI & 11,360 & 360 & 7,845 & 880 & 1,268 & 313 \\
\hline FR & 72,700 & 2,550 & 34,690 & 11,578 & 2,138 & 593 \\
\hline GR & 10,967 & 301 & 4,564 & 804 & 10,070 & 12 \\
\hline HR & 16,051 & 189 & 1,908 & 404 & 525 & 25 \\
\hline $\mathrm{HU}$ & 47,430 & 868 & 3,454 & 769 & 339 & 84 \\
\hline IE & 7,706 & 218 & 2,717 & 822 & 676 & 70 \\
\hline IT & 111,733 & 2,031 & 26,233 & 7,804 & 770 & 534 \\
\hline LT & 3,840 & 201 & 1,310 & 275 & 195 & 50 \\
\hline LU & 526 & 29 & 897 & 184 & 34 & 23 \\
\hline LV & 9,688 & 128 & 898 & 183 & 1,935 & 36 \\
\hline MT & 0 & 4 & 1,032 & 18 & 265 & 23 \\
\hline NL & 2,149 & 825 & 4,876 & 1,512 & 368 & 372 \\
\hline NO & 16,753 & 234 & 2,630 & 854 & 1,244 & 0 \\
\hline PL & 110,409 & 2,679 & 11,064 & 4,961 & 20,715 & 424 \\
\hline PT & 16,539 & 393 & 4,958 & 1,078 & 428 & 92 \\
\hline RO & 92,178 & 1,005 & 5,148 & 954 & 5,335 & 50 \\
\hline SE & 5,826 & 482 & 16,320 & 1,075 & 1,213 & 211 \\
\hline SI & 8,902 & 65 & 1,208 & 441 & 363 & 32 \\
\hline SK & 28,106 & 183 & 1,685 & 622 & 564 & 70 \\
\hline UK & 45,901 & 2,997 & 21,802 & 7,306 & 5,026 & 219 \\
\hline Total & 793,396 & 26,022 & 223,487 & 67,304 & 79,270 & 6,075 \\
\hline
\end{tabular}

Source Own illustration 


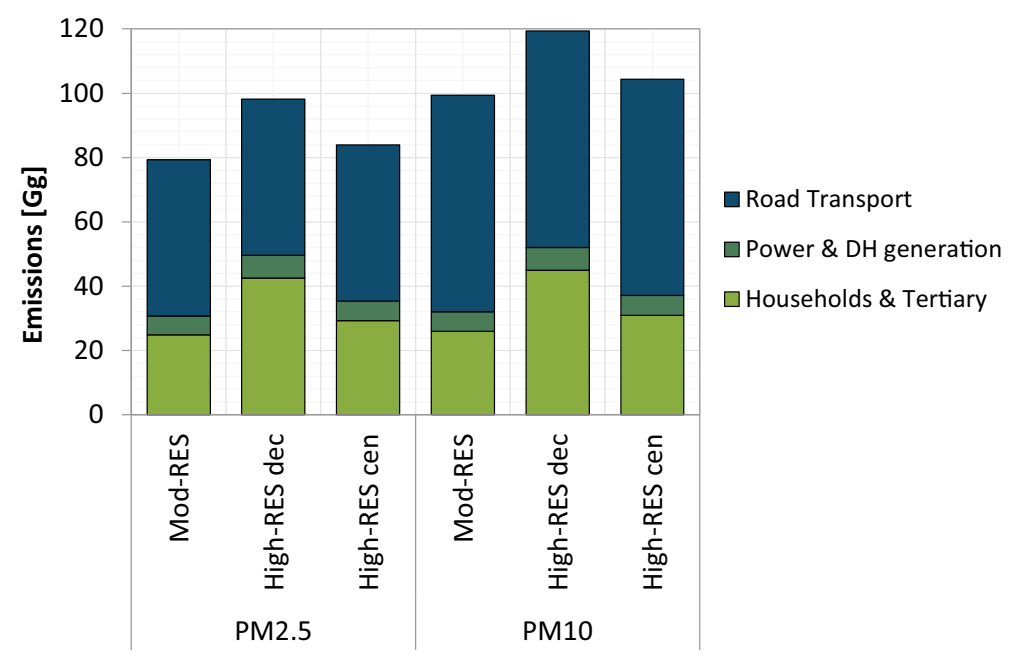

Fig. 15.2 Emissions of $\mathrm{PM}_{10}$ and $\mathrm{PM}_{2.5}$ in 2050 for different REFLEX scenarios. (Source Own illustration)

2015 and 2050 from the power and district heat sector, road transport, residential and tertiary sector that are used as an input to the air quality modeling.

Total $\mathrm{PM}_{10}$ emissions in 2015 from all the sectors and countries presented in Table 15.1 equaled to approx. 1 million ton. Figure 15.2 shows particulate matter emissions for different REFLEX scenarios in 2050.

According to the scenarios PM emissions in the sectors listed in Table 15.1 are reduced by 10 times until 2050. In all REFLEX scenarios the climate-oriented goals strongly support the development of renewable energy sources. The most significant reduction is observed for the residential and tertiary sector where the fuel and technology switch take place. Particularly, high reductions occur in 2050 in Eastern European countries such as Poland, Bulgaria, which are now struggling with large emissions from the residential sector (Table 15.1). The difference in results between the REFLEX scenarios is relatively small (Fig. 15.2). A larger difference occurs in the residential and tertiary sector than in the power and district heating sector. It is mainly due to the different structural use of solid biomass for heating. Figure 15.3 shows the solid biomass consumption for different sectors according to the results of the REFLEX energy models. In fact, biomass is covering a significant proportion of the EU's heat demand at present (EEA 2016) and in the REFLEX scenarios it maintains to play an important role in the future.

Figure 15.3 indicates that in the High-RES decentralized scenario $\mathrm{PM}_{2.5}$ emissions are higher than in the High-RES centralized case. The main reason is that in the former, more biomass is directly used by households for heating (in installations meeting the Ecodesign emission standards). In the latter, more biomass is used in CHPs, for which stricter emission standards are assumed. Hence, the use of biomass as residential fuel is on one hand leading to reduction of $\mathrm{CO}_{2}$ emissions but on the 


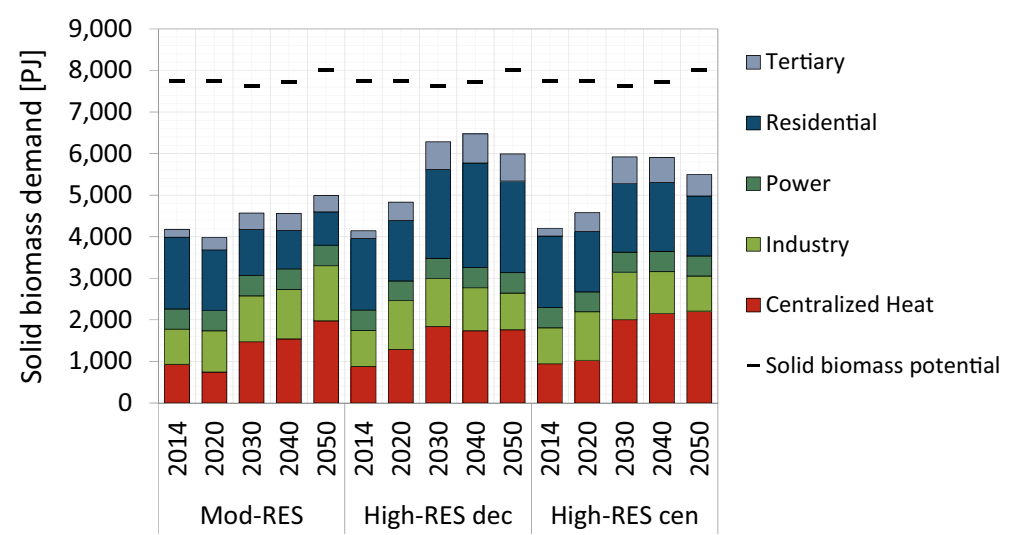

Fig. 15.3 Solid biomass consumption for different sectors according to the results of the REFLEX energy models [PJ]. (Source Own illustration)

other is causing higher $\mathrm{PM}_{2.5}$ emissions from this sector due to less strict emission standards for residential heating.

\subsubsection{Air Quality Modeling}

Ambient concentration of air pollutants is calculated with the use of the Polyphemus Air Quality System for each REFLEX emissions scenario. Polyphemus is a complex modeling system for air quality (Mallet et al. 2007; Zyśk et al. 2015). It contains two types of dispersion models: Gaussian and Eulerian. In this modeling exercise an Eulerian chemistry-transport-model called Polair3D is used for both gaseous and aerosol species. Polair3D tracks multiphase chemistry: (i) gas, (ii) water and (iii) aerosols. The transport driven by wind is approached with the third order direct space time (DST3) and the piecewise parabolic method (PPM). Gas-phase chemical scheme is RACM (also other chemical schemes e.g. CB05, RADM 2, Melchior) are available. Aerosol chemistry is treated depending on the cloud liquid water content. Inside clouds, aqueous-phase chemical reactions are modeled using the Variable Size-Resolution Model (VSRM). Outside clouds, a size-resolved aerosol model (SIREAM) treats the effects of condensation/evaporation, coagulation and nucleation upon the particle size distribution. The ISORROPIA module is used for inorganic aerosol thermodynamics.

The main equation for the chemistry-transport that Polair3D solves numerically includes three terms: (i) advection (transport driven by wind), (ii) diffusion (mainly turbulent mixing in the vertical layer) and (iii) chemistry (chemical production as well as dry and wet deposition) (Boutahar et al. 2004).

Running Polyphemus requires, inter alias, preparation of external databases, such as meteorological fields, emission databases, land use coverage (and miscellaneous 
data associated with land categories), pollutant concentrations at higher scales (e.g. global concentrations, which constitute the boundary conditions for continental simulations), and physical parameters associated with chemical species. The meteorological parameters are taken from the European Centre for Medium-Range Weather Forecasts (ECMWF) meteorological data for 2008. The ECMWF data are provided with a geographical resolution of $0.25^{\circ}$ on 54 vertical levels every $3 \mathrm{~h}$. Running the simulation requires also: (i) calculation of biological and sea salt emission, (ii) preparation of the ground emissions, (iii) generation of the meteorological fields, (iv) generation of the initial and boundary conditions, (v) calculation of the dry deposition velocity.

The analysis is performed for a domain covering Europe with the geographical extend of $12.0^{\circ} \mathrm{W}, 27^{\circ} \mathrm{E}$ of longitude and $35.0^{\circ} \mathrm{N}-69^{\circ} \mathrm{N}$ of latitude. This mesh consists of $40 \times 34$ cells with a horizontal resolution of $1.0^{\circ} \times 1.0^{\circ}$ (along longitude and latitude respectively. Five vertical levels are used with the following limits [in meters above surface]: $0,50,600,1,200,2,000,3,000$. Setting the simulation is run with the time step of $10 \mathrm{~min}$ and results are saved each $1 \mathrm{~h}$.

\subsubsection{Health Impacts and External Costs}

Over the last decades, many studies have been carried out on the health impacts of human exposure to elevated concentrations of air pollutants (both short and longterm). These include, inter alias, observational and experimental human studies, animal studies and in vitro studies (Bickel and Friedrich 2005). In one of the most well-known research papers described in the literature, Pope et al. (2002) analyze the relationship between long-term exposure to fine particulate air pollution and find that each $10-\mathrm{mg} / \mathrm{m}^{3}$ elevation in fine particulate air pollution is associated with approximately $6 \%$ increased mortality. The results of the studies show that air pollution aggravates human's morbidity (especially respiratory and cardiovascular diseases) and leads to premature death i.e., deaths that occur before a person reaches an expected age (WHO 2018; EEA 2018).

The approach to estimate the health impacts of air pollution applied in this study is largely based on the methodology developed within a series of the ExternE projects (European Commission 1999). According to ExternE, fine particulate matter with an aerodynamic diameter of $2.5 \mathrm{~mm}$ or less (primary and airborne), is responsible for the most significant impacts to human health. Health impacts considered in this study are limited to people's long-term exposure to fine particulate $\left(\mathrm{PM}_{2.5}\right)$ air pollution. The prevailing health damages caused by PMs are: loss life expectancy, chronic bronchitis and restricted activity days (Rabl and Spadaro 2008). Loss of Life Expectancy (LLE) is an indicator often used as a proxy for quantifying the overall impact on a population's health. It is found suitable for the comparative analysis of energy scenarios (Amann et al. 2011). It is expressed in the years of life lost (YOLLs) being an estimate of the average years that a person would have lived if he or she had not died prematurely. Chronic bronchitis (CB) refers to newly observed cases, but not to change 
Table 15.2 Slopes and unit values of considered CRFs for $\mathrm{PM}_{2.5}$

\begin{tabular}{l|l|l|l}
\hline CRF function (effects) & $\begin{array}{l}\text { CRF } \\
{\left[\text { cases } \mu \mathrm{g}^{-1} \mathrm{~m}^{-3}\right]}\end{array}$ & $\begin{array}{l}\mathrm{Fr} \\
{[\%]}\end{array}$ & $\begin{array}{l}\text { Unit value } \\
{\left[\mathrm{EUR}_{2013} \text { case }^{-1 *}\right]}\end{array}$ \\
\hline $\mathrm{PM}_{2.5}$ - Mortality YOLL & $3,42 \mathrm{E}-04$ & 100 & 57,510 \\
\hline $\mathrm{PM}_{2.5}$ - Chronic Bronchitis & $3,90 \mathrm{E}-05$ & 80 & 38,578 \\
\hline $\mathrm{PM}_{2.5}-$ Restricted Activity Days & $4,20 \mathrm{E}-02$ & 80 & 98 \\
\hline
\end{tabular}

*Case means: YOLL, RAD, CB

in the prevalence illness rate among adults. Restricted Activity Days (RAD) corresponds to days when an individual's routine activities are disrupted. Health impacts (I) are calculated using the concentration-response functions (CRFs), which relate the quantity of a pollutant that affects a population (accounting for the absorption of the pollutant from the air into the body) to the physical impact (Eq. 15.1).

$$
I=\text { Con } \cdot P o p \cdot F r \cdot C R F
$$

Where: $I$ is the health impact of a given type (i.e. years of life lost - YOLL, restricted activity days-RAD or chronic bronchitis-CB), Con is the concentration of $\mathrm{PM}_{2.5}\left[\mu \mathrm{g} / \mathrm{m}^{3}\right]$, Pop denotes the population exposed, $\mathrm{Fr}$ is the fraction of population affected and $C R F$ is the concentration-response function for a given impact type. $\mathrm{PM}_{2.5}$ impacts have been estimated for the full range of observed concentrations.

In the next step, the monetary values (leading to external costs) are assigned to respective health impacts. In case of loss of life expectancy, the cost of mortality is estimated usually as the willingness-to-pay to avoid the risk of an anonymous premature death. Cost of chronic bronchitis expresses all medical treatment expenses over the patient's lifetime. Restricted activity days takes into account cost of illnesses, loss of productivity and welfare loss.

The monetary values and CRFs used in the study, which have been derived from the results of ExternE (Bickel and Friedrich 2005), vetcen database (Holland and Watkiss 2002) and AQMEII3 initiative (Ulas et al. 2018) are presented in Table 15.2.

In addition to the parameters presented in Table 15.2, information on ambient $\mathrm{PM}_{2.5}$ concentrations and demographic data are also required to calculate the health impacts and external costs (Eq. 15.1). Ambient pollutants concentrations are calculated using Polyphemus air quality system. The demographic data are taken from GEOSTAT 2011. This dataset includes population distribution with $1 \mathrm{~km} \times 1 \mathrm{~km}$ spatial resolution.

\subsection{Results}

Following the DPSIR logic at first the results of atmospheric dispersion of PMs are presented. Figure 15.4 shows modeled ambient $\mathrm{PM}_{2.5}$ concentration at surface level in 


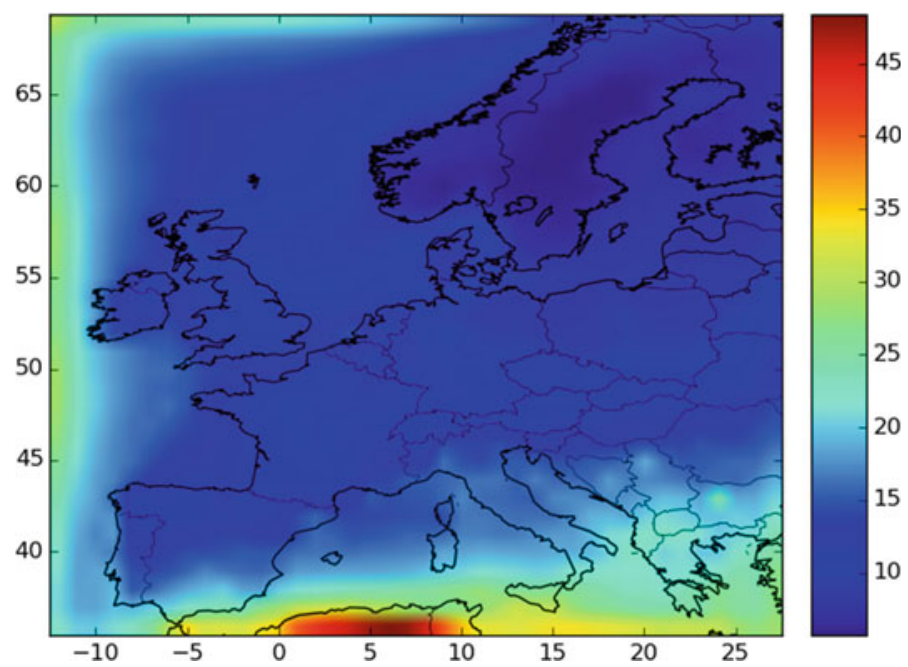

Fig. 15.4 Modeled ambient $\mathrm{PM}_{2.5}$ concentration at surface level in 2050 for Mod-RES scenario $\left[\mu \mathrm{m} / \mathrm{m}^{3}\right]$. (Source Own illustration)

2050 for the Mod-RES scenario in which, as presented in Fig. 15.2, PM emissions are the lowest. Figure 15.5 shows the change in ambient $\mathrm{PM}_{2.5}$ concentrations between 2015 and 2050 for the Mod-RES scenario.

According to the Mod-RES scenario, the average annual ambient concertation of $\mathrm{PM}_{2.5}$ in the EU-27, Norway, Switzerland and the United Kingdom will be lower

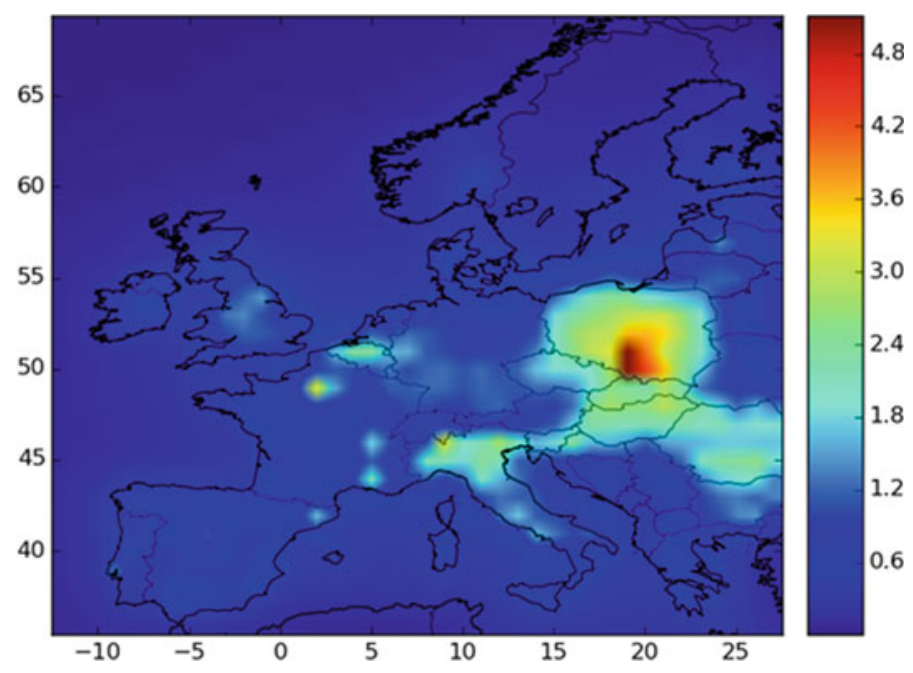

Fig. 15.5 Difference between modeled ambient $\mathrm{PM}_{2.5}$ concentration at surface level in 2015 based on EMEP emission data and in 2050 for Mod-RES scenario $\left[\mu \mathrm{m} / \mathrm{m}^{3}\right]$. (Source Own illustration) 
than $15 \mu \mathrm{g} / \mathrm{m}^{3}$ in 2050 . The lowest concertation is observed in Scandinavian countries and highest over Mediterranean countries because of significant share of the natural particulate matter from Sahara (cf. Figure 15.4). The largest reduction in $\mathrm{PM}_{10}$ ambient concentrations is observed over Poland (cf. Figure 15.5). This is mainly caused by reduction of emissions form the residential sector. Nowadays in Poland more than $40 \%$ of houses and flats use inefficient and highly polluting solid fuel boilers (mainly coal and some biomass) for heating. Reducing the amount of coal burned in this sector and the use of modern boilers meeting the Ecodesign limits will lead to significant improvement of air quality over Poland.

The results of the health impact assessment for 2015 and for the Mod-Res scenario in 2050 are presented in Table 15.3. The health effects are almost the same for the High-RES scenarios due to similar PM emissions and ambient pollutants concentration levels in these scenarios. In total, in the countries presented in Table 15.3 almost 2.2 million YOLL are attributed to $\mathrm{PM}_{2.5}$ exposure in 2050.

The results presented in Table 15.3 show that the negative health impact associated with the fine particulate air pollution in 2050 is lower than in 2015 in all the countries. The cumulative number of years of life lost is estimated to be the highest (both in 2015 and 2050) in highly populated countries like Italy, Germany, France, Spain, United Kingdom and Poland. The highest reduction in negative health impacts is observed in Poland (25\%), Slovakia (19\%), Hungary (16.5\%) and Czech Republic $(16 \%)$. The smallest reduction is observed in Malta and Greece.

Figure 15.6 show the difference between the value of YOLL in 2015 and 2050 (Mod-RES scenario) at the grid-cell level. The greatest reduction in overall value of years of life lost (health benefits) takes place in cells located in Poland, northern Italy, Germany, Romania and United Kingdom. This reduction in YOLL in 2050 corresponds to the modeled decrease in ambient $\mathrm{PM}_{2.5}$ concentration over the areas as shown in Fig. 15.6.

The calculated health impacts are used to estimate the value of external costs, which are presented in Table 15.4.

As presented in Table 15.4 the estimated health related external costs attributed to $\mathrm{PM}_{2.5}$ exposure for the impact types considered in this study are estimated at about 170 billion EUR per year in 2015. The estimated reduction of external costs according to Mod-RES scenario in 2050 reaches almost 20 billion EUR per year. The significant reduction of PM emissions by 2050 from the sectors considered in this study do not yield a proportional decrease of ambient PM concentration. Hence, also health benefits are moderate. One should bear in mind, that in our study the future emissions from others sector are maintained at a constant 2015 level. The same applies to the boundary conditions that take into account the inflow of PMs emitted outside of the analyzed domain. Moreover, also natural (non-anthropogenic or biogenic) sources, including windblown dust and wildfires contribute to the overall PM problem. 
Table 15.3 Health impacts attributable to air pollution of $\mathrm{PM}_{2.5}$ in 2015 and 2050 (for the High-RES centralized scenario)

\begin{tabular}{|c|c|c|c|c|c|c|}
\hline \multirow[b]{2}{*}{ Country } & \multicolumn{3}{|l|}{2015} & \multicolumn{3}{|l|}{2050} \\
\hline & $\begin{array}{l}\text { YOLL } \\
{\left[\times 10^{3}\right]}\end{array}$ & $\begin{array}{l}\text { RAD } \\
{\left[\times 10^{5}\right]}\end{array}$ & $\begin{array}{l}\text { CB } \\
{\left[\times 10^{2}\right]}\end{array}$ & $\begin{array}{l}\text { YOLL } \\
{\left[\times 10^{3}\right]}\end{array}$ & $\begin{array}{l}\text { RAD } \\
{\left[\times 10^{5}\right]}\end{array}$ & $\begin{array}{l}\text { CB } \\
{\left[\times 10^{2}\right]}\end{array}$ \\
\hline AT & 35.31 & 34.69 & 32.21 & 31.95 & 31.39 & 29.15 \\
\hline $\mathrm{BE}$ & 54.74 & 53.78 & 49.94 & 46.75 & 45.93 & 42.65 \\
\hline BG & 46.96 & 46.14 & 42.84 & 44.14 & 43.36 & 40.27 \\
\hline $\mathrm{CH}$ & 33.66 & 33.07 & 30.70 & 30.96 & 30.42 & 28.25 \\
\hline $\mathrm{CZ}$ & 42.32 & 41.57 & 38.60 & 35.52 & 34.89 & 32.40 \\
\hline $\mathrm{DE}$ & 327.12 & 321.38 & 298.42 & 297.22 & 292.01 & 271.15 \\
\hline DK & 18.38 & 18.06 & 16.77 & 17.19 & 16.89 & 15.68 \\
\hline $\mathrm{EE}$ & 3.53 & 3.46 & 3.22 & 3.33 & 3.27 & 3.04 \\
\hline EL & 84.66 & 83.18 & 77.24 & 82.09 & 80.65 & 74.89 \\
\hline ES & 252.60 & 248.17 & 230.44 & 241.27 & 237.03 & 220.10 \\
\hline FI & 12.45 & 12.23 & 11.36 & 11.80 & 11.59 & 10.76 \\
\hline FR & 270.22 & 265.48 & 246.52 & 242.68 & 238.42 & 221.39 \\
\hline $\mathrm{HR}$ & 22.94 & 22.53 & 20.92 & 20.66 & 20.29 & 18.84 \\
\hline $\mathrm{HU}$ & 49.04 & 48.18 & 44.74 & 40.96 & 40.24 & 37.36 \\
\hline IE & 21.34 & 20.96 & 19.46 & 20.60 & 20.24 & 18.80 \\
\hline IT & 376.38 & 369.77 & 343.36 & 342.16 & 336.16 & 312.15 \\
\hline LT & 10.04 & 9.87 & 9.16 & 9.00 & 8.84 & 8.21 \\
\hline $\mathrm{LV}$ & 6.29 & 6.18 & 5.73 & 5.59 & 5.49 & 5.10 \\
\hline MT & 4.82 & 4.73 & 4.39 & 4.78 & 4.70 & 4.36 \\
\hline NL & 74.43 & 73.12 & 67.90 & 68.77 & 67.57 & 62.74 \\
\hline $\mathrm{NO}$ & 12.90 & 12.68 & 11.77 & 12.21 & 12.00 & 11.14 \\
\hline PL & 165.31 & 162.41 & 150.81 & 124.50 & 122.32 & 113.58 \\
\hline PT & 59.26 & 58.22 & 54.06 & 56.14 & 55.15 & 51.21 \\
\hline $\mathrm{RO}$ & 101.66 & 99.88 & 92.75 & 89.63 & 88.06 & 81.77 \\
\hline SE & 24.23 & 23.81 & 22.11 & 23.11 & 22.70 & 21.08 \\
\hline SI & 10.02 & 9.84 & 9.14 & 8.79 & 8.64 & 8.02 \\
\hline SK & 25.19 & 24.75 & 22.98 & 20.42 & 20.07 & 18.63 \\
\hline UK & 255.30 & 250.82 & 232.90 & 234.30 & 230.19 & 213.75 \\
\hline Total & $2,401.07$ & $2,358.95$ & $2,190.45$ & $2,166.54$ & $2,128.53$ & $1,976.49$ \\
\hline
\end{tabular}

Source Own illustration 
Yoll [cases/yr]

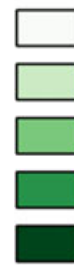

$0.0-168.5$

$168.5-628.2$

$628.2-1578.4$

$1578.4-6347.3$

$6347.3-10907.4$

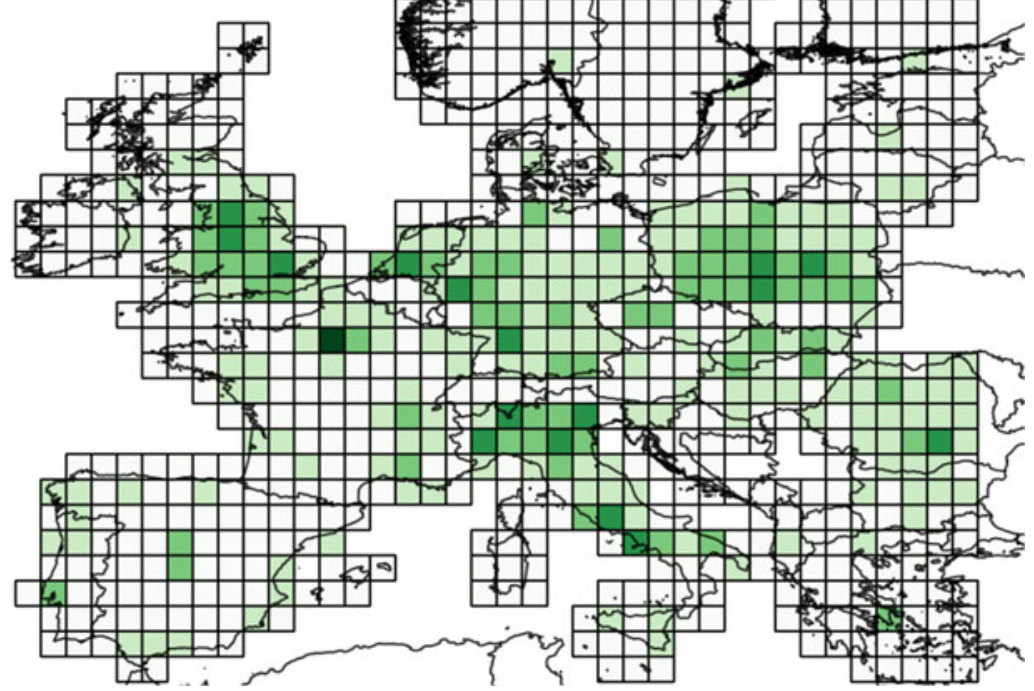

Fig. 15.6 The difference between the value of YOLL in 2015 and 2050 (High-RES centralized scenario) at the grid-cell level. Green color shows the benefits resulting from better air quality. (Source Own illustration)

Table 15.4 Annual external attributed to $\mathrm{PM}_{2.5}$ exposure in 2015 and 2050 (Mod-RES)

\begin{tabular}{l|l|l|l|l|l}
\hline \multirow{2}{*}{ Type } & \multicolumn{4}{l}{ Health impacts } & External costs \\
\cline { 2 - 6 } & $\begin{array}{l}2015 \\
{\left[10^{3} \text { cases }\right]}\end{array}$ & $\begin{array}{l}2050 \\
{\left[10^{3} \text { cases }\right]}\end{array}$ & $\begin{array}{l}\text { Monetary value } \\
{\left[E_{2013} \text { case }^{-1}\right]}\end{array}$ & $\begin{array}{l}2015 \\
{\left[10^{9} \text { EUR }\right]}\end{array}$ & $\begin{array}{l}2050 \\
{\left[10^{9} \text { EUR }\right]}\end{array}$ \\
\hline YOLL & 2401 & 2166 & 57,510 & 138.0 & 124.6 \\
\hline RAD & 235,895 & 212,853 & 98 & 23.1 & 20.9 \\
\hline CB & 219 & 198 & 38,578 & 8.5 & 7.6 \\
\hline Total & & & & 169.6 & 153.1 \\
\hline
\end{tabular}

\subsubsection{Summary and Conclusions}

In this study the air quality and health impacts of direct emissions of pollutants associated with the energy scenarios elaborated within the REFLEX project are 
assessed. According to the REFLEX scenarios, the emission in 2050 as compared to 2015 will be ca. 30 times lower in the residential and tertiary sector, 3 times lower in road transport and 12 times lower in the power and district heating generation. This is caused both by limiting the combustion of solid fuels and by improving combustion methods. The difference in $\mathrm{PM}_{2.5}$ emissions between REFLEX scenarios in 2050 is insignificant. This is mainly due to the different structural use of solid biomass for heating. In decentralized scenario, with higher emissions, more biomass is directly used by households. In centralized scenario, biomass is used in combined heat and power plants with better emission control.

Results show that as compared to the situation in 2015 there are improvements in air quality and also the negative health effects are reduced in 2050 in all REFLEX scenarios. The largest of $5 \mu \mathrm{g} / \mathrm{m}^{3}$ improvement in air quality regarding $\mathrm{PM}_{2.5}$ concertation is observed in Poland. Increasing the spatial resolution of the air quality modeling domain would allow to observe even greater differences of concentration in some areas, as the reduction of emissions per unit area would be even greater. Choice of the settings is dictated by the high requirements of computational resources and the computation time, which significantly increases with the increase in resolution. Generally, a greater improvement in air quality is observed in Eastern and Central Europe due to the significant reduction of emissions from the residential sector. The cumulative number of years of life lost in the Mod-RES scenario in 2050 amount to almost 2.2 million. The results of the health impact assessment are almost the same for the High-RES scenarios due to similar PM emissions and ambient pollutants concentration levels in these scenarios. The estimated reduction of external costs according to Mod-RES scenario in 2050 as compared to 2015 situation reaches almost 20 billion EUR per year.

In this study the changes of PM emissions only from selected sectors (i.e. road transport, power and district heating generation, households and tertiary sector) are taken into account. Anthropogenic emissions from other sectors such as e.g., industry or agriculture are maintained at a constant 2015 level. The same applies to the natural emissions and to the boundary conditions that take into account the inflow of PMs emitted outside of the analyzed domain. Therefore, the significant reduction in PM emissions observed in the analyzed sectors in 2050 do not yield a proportional decrease of ambient PM concentration. Hence, also health benefits, which take place in all the countries, are moderate. The results show that the situation with regard to fine particulate air pollution and associated health impact will continue to improve in the future due to two main factors. Firstly, exhaust systems are getting improved and the effectiveness of flue gas cleaning is increasing. Secondly, the role of fossil fuels (i.e. their combustion) will decrease. 


\section{References}

Amann M, Bertok I, Borken-Kleefeld J, Cofala J, Heyes C, Hooglund-Isaksson L, Klimont Z, Nguyen B, Posch M, Rafaj P, Sandler R, Schopp W, Wagner F, Winiwarter W (2011) Costeffective control of air quality and greenhouse gases in Europe: modeling and policy applications. Environ Model Softw 26(12), 1489-1501. https://doi.org/10.1016/j.envsoft.2011.07.012

Bickel P, Friedrich R (2005) Externalities of energy methodology 2005 update. European Commission

Boutahar J, Lacour S, Mallet V, Quélo D, Roustan Y, Sportisse B (2004) Development and validation of a fully modular platform for numerical modelling of air pollution: POLAIR. International Journal of Environment and Pollution, 22 (1/2), 17-28. https://doi.org/10.1504/ijep.2004.005474

Commission Regulation (EU) (2015) Commission Regulation (EU) 2015/1189 of 28 April 2015 implementing Directive 2009/125/EC of the European Parliament and of the Council with regard to ecodesign requirements for solid fuel boilers (Text with EEA relevance)

Directive EU (2008) Directive 2008/50/EC of the European Parliament and of the Council of 21 May 2008 on ambient air quality and cleaner air for Europe (CAFE)

Directive EU (2010) Directive 2010/75/EU of the European Parliament and of the Council of 24 November 2010 on industrial emissions (integrated pollution prevention and control)

EEA (2016) Air quality in Europe - 2016 report; EEA Report No 28/2016

EEA (2018) Air quality in Europe - 2018 report; EEA Report No 12/2018

EMEP (2018) The European Monitoring and Evaluation Program [online]. Available from: http:// www.emep.int/

European Commission (1999) ExternE Externalities of Energy Vol XX : National Implementation

GAINS (2019) GAINS-model Greenhouse Gas and Air Pollution Interactions and Synergies, IIASA The International Institute for Applied Systems Analysis [online]

Guariso G, Volta M (2017) Air Quality Integrated Assessment; A European Perspective

Holland M, Watkiss P (2002) Estimates of the marginal external costs of air pollution in Europe. Created for European Commission DG Environment by netcen

Mallet V, Quello D, Sportisse B, Ahmed de Biasi M, Debry E, Korsakissok I, Wu L, Roustan Y, Sartelet K, Tombette M, Foudhil H (2007) Technical Note: The air quality modeling system Polyphemus. Atmos Chem Phys, 7 (20), 5479-5487. https://doi.org/10.5194/acp-7-5479-2007

Pope CA, Burnett RT, Thun MJ, Calle EE, Krewski D, Ito K, Thurston GD (2002) Lung cancer, cardiopulmonary mortality, and long-term exposure to fine particulate air pollution. Journal of the American Medical Association, 287 (9), 1132-1141. https://doi.org/10.1001/jama.287.9.1132

Rabl A, Spadaro JV (2008) Estimating the uncertainty of damage costs of pollution: A simple transparent method and typical results. Environmental Impact Assessment Review Volume, 28, 166-183. https://doi.org/10.1016/j.eiar.2007.04.001

Ulas I, Brandt J, Geels C, Mantzius Hansen K, Heile Christensen J, Skou Andersen M, Solazzo E, Kioutsioukis I, Alyuz U, Balzarini A, Baro R, Bellasio R, Bianconi R, Bieser J, Colette A, Curci G, Farrow A, Flemming J, Fraser A, Jimenez-Guerrero P, Kitwiroon N, Liang CK, Pirovano G, Pozzoli L, Prank M, Rose R, Sokhi R, Tuccella P, Una A, Garcia Vivanco M, West J, Yarwood G, Hogrefe C, Galmarini S (2018) Assessment and economic valuation of air pollution impacts on human health over Europe and the United States as calculated by a multi-model ensemble in the framework of AQMEII3. Atmos Chem Phys, 18, 5967-5989. https://doi.org/10.5194/acp2017-751

WHO (2018) World Health Organization. Global Health Observatory (GHO) data. Mortality from household air pollution

Wyrwa A (2015) An optimization platform for Poland's power sector considering air pollution and health effects. Environmental Modelling \& Software, 74, 227-237. https://doi.org/10.1016/j.env soft.2015.04.017

Zyśk J, Roustan Y, Wyrwa A (2015) Modelling of the atmospheric dispersion of mercury emitted from the power sector in Poland. Atmospheric Environment, 112, 246-256. https://doi.org/10. 1016/j.atmosenv.2015.04.040 
Open Access This chapter is licensed under the terms of the Creative Commons Attribution 4.0 International License (http://creativecommons.org/licenses/by/4.0/), which permits use, sharing, adaptation, distribution and reproduction in any medium or format, as long as you give appropriate credit to the original author(s) and the source, provide a link to the Creative Commons license and indicate if changes were made.

The images or other third party material in this chapter are included in the chapter's Creative Commons license, unless indicated otherwise in a credit line to the material. If material is not included in the chapter's Creative Commons license and your intended use is not permitted by statutory regulation or exceeds the permitted use, you will need to obtain permission directly from the copyright holder.

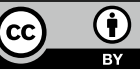

